\title{
Medico-Legal Autopsy \& Forensic Science Laboratory: Vital Tools of Criminal Justice System
}

Vijay Kumar $\mathrm{AG}^{*}$, Kumar U, Shivaramu MG and Vinay J

Department of Forensic Medicine and Toxicology, Adichunchanagiri Institute of Medical Sciences, Karnataka, India

*Corresponding author: Vijay Kumar AG, Associate professor, Department of Forensic Medicine and Toxicology, Adichunchanagiri Institute of Medical Sciences, Karnataka, India, Tel: +919916735739 ; E-mail: vijay.fmt@rediffmail.com

Received date: October 06, 2018; Accepted date: December 04, 2018; Published date: December 11, 2018

Copyright: (c) 2018 Vijay Kumar AG, et al. This is an open-access article distributed under the terms of the Creative Commons Attribution License, which permits unrestricted use, distribution, and reproduction in any medium, provided the original author and source are credited.

\begin{abstract}
Forensic science is the application of science and technology to the detection and investigation of crime. Forensic science has shaped the world of justice, signifying the examination of crime with the help of modern and advanced technology. In this retrospective study, the viscera sent to toxicology and DNA section of FSL during autopsy at mortuary of Adichunchanagiri Institute of Medical Sciences, Mandya district, Karnataka, India, between January 2013 to December 2017 were analyzed. During this study, several epidemiological observations and their results were considered. Out of 748 autopsied cases, in 256 cases viscera has been forwarded to Toxicology section of forensic science laboratory and in 43 unidentified bodies either femur bone or liver tissue has been forwarded to DNA section. In all the 256 cases viscera has been subjected to toxicological examination at forensic science laboratory, in that 211 cases we received positive results, stating the type and amount of poison present at the time of death. In 43 cases viscera has been forwarded to DNA section, and the report has been forwarded to honorable court. With the rising population combined with inflation and economic downturns, there is an increased spurt of crime rates of all natures in the society. To ensure adequate and timely justice to the victims of offences a proper autopsy coupled with laboratory backing will go a long way in supplementing the work of police investigation in order to convert suspicion into a reasonable certainty of either guilt or innocence.
\end{abstract}

Keywords: Autopsy; Forensic science laboratory; Justice system

\section{Introduction}

Forensic medicine is a branch of science; which deals with the application of medical knowledge to aid in the administration of justice. Forensic science is the application of medical knowledge, scientific knowledge and technical aspects to solve the crime and to aid in justice.

Forensic Science Laboratories are located at all district headquarters all over the India. The scientist of forensic science laboratory, they teach investigating officer regarding the right methods of collection of evidences at crime scene and they analyze all the evidences with this they do help the investigation process.

Forensic Science Laboratories are multi-disciplinary system, well equipped with extremely specialized and rationalized infrastructure of international standards. It is competent of carrying out any challenging scientific work related to crime. The directorate analyses various criminal cases under different laws like I.P.C., Cr.P.C, Indian Arms Act, NDPS Act, Explosive Substances Act, Petroleum Act, Mumbai Police Act, Essential Commodities Act, Bombay Prohibition Act, Motor Vehicle Act, I.T.Act, Wild Life Protection Act, TADA, MCOCA etc and provides scientific analytical reports [1].

\section{Toxicology section}

Systematic analysis and quantitation of poison levels is done by using advanced instrumental techniques like Gas Chromatography, Spectrophotometer, and High Performance Thin Layer Chromatography (HPTLC) with Scanner to ensure successful prosecution. In this division, viscera, stomach wash/aspirate, vomit, blood and other biological/non- biological material submitted by the Medical and Police officers in homicidal and suicidal poisoning cases are examined for the detection of poison, if any, present therein [1].

\section{DNA section}

Over last 25 years forensic science has gained tremendous grounds as far as evidential values are concerned due to one particular biological tool that is the analysis of DNA. It has revolutionized forensic investigations. The DNA division of this laboratory is well equipped with modern instruments. DNA analysis has broad application in forensic such as disputed paternity testing, murder, rape, individualization etc. The conventional use of immunological and polymorphic enzyme systems, works best in exclusion cases, but chance of inclusion does not exceed above $99.7 \%$. In DNA profiling the probability of identical pattern between the two randomly selected individuals is in order of 1 in 1014 to 1030, keeping in mind the world's population which is approximately $5 \times 1016$. Thus the DNA profile can be considered highly unique (except monozygotic twins) [1].

\section{Materials and Methods}

In this retrospective study, the viscera sent to toxicology and DNA section of FSL during autopsy at mortuary of Adichunchanagiri Institute of Medical Sciences, Mandya district, Karnataka, India, between January 2013 to December 2017 were analyzed.

Viscera to be forwarded in all suspected case of poisoning and alcohol are:

1. Stomach and contents-preservative-common salt solution. 
Page 2 of 3

2. Pieces of liver and kidney-preservative- common salt solution.

3. Blood- preservative-sodium fluoride.

4. Common salt solution-control.

Viscera to be forwarded in all unknown bodies for DNA analysis are:

1. Femur bone-no preservative required.

2. Pieces of liver-preservative-normal saline.

Method of sampling at forensic science laboratory:

1. Finely minced tissue samples, blood, preservative were subjected to steam distillation and the distillate collected.

2. Finely minced tissue samples, blood, preservative were subjected to Liquid-Liquid Extraction (LLE) with dichloromethane/diethyl ether/ethyl acetate at acidic, neutral and basic $\mathrm{pH}$. After phase separation, the organic layer was purified, evaporated to dryness and reconstituted with methanol.

3. Finely minced tissue samples, blood, preservative were added with zinc granule and acidified. The resulting fumes were passed through SDDC-morpholine reagent.

4. Finely minced tissue samples, blood, preservative were subjected to wet digestion/protein precipitation and filtered.

Method of analysis \& identification at forensic science laboratory:

1. Distillate from the sampling method 1 was analyzed for alcohols by color tests and volumetric titration/gas chromatography.

2. Extract from the sampling method 2 was analyzed for pesticides, drugs and alkaloids by color tests and thin-layer chromatography methods/high-performance thin-layer chromatography.

3. Distillate from the sampling method 1 was analyzed for cyanide by color tests.

4. Filtrate from the sampling method 4 was analyzed for toxic metal ions and anions by color tests.

5. The reagent from the sampling method 3 was analyzed for phospide ions by color tests and UV-visible spectrophotometry.

\begin{tabular}{|l|l|l|l|}
\hline Year & $\begin{array}{l}\text { Total no. of } \\
\text { autopsies }\end{array}$ & $\begin{array}{l}\text { Viscera sent to } \\
\text { toxicology section }\end{array}$ & $\begin{array}{l}\text { Viscera sent to } \\
\text { DNA section }\end{array}$ \\
\hline 2013 & 140 & 41 & 2 \\
\hline 2014 & 158 & 44 & 6 \\
\hline 2015 & 138 & 52 & 9 \\
\hline 2016 & 148 & 58 & 11 \\
\hline 2017 & 164 & 61 & 15 \\
\hline Total & 748 & 256 & 43 \\
\hline
\end{tabular}

Table 1: Statistics of toxicological examination.

\section{Results}

Out of 748 autopsied cases, in 256 cases viscera has been forwarded to Toxicology section of forensic science laboratory and in 43 unidentified bodies either femur bone or liver tissue has been forwarded to DNA section.

In all the 256 cases viscera has been subjected to toxicological examination at forensic science laboratory, in that 211 cases we received positive results, stating the type and amount of poison present at the time of death. In 43 cases viscera has been forwarded to DNA section, and the report has been forwarded to honourable court (Table $1)$.

\section{Discussion}

The main functions of forensic science laboratory are [2]:

1. To reconstruct a crime.

2. To analyze trace evidence (blood, hair, fiber, etc from victim, accused and the scene of crime and to link the three together), this work is carried on by different sections.

Forensic science laboratory provides services for scientific examination and evaluation of evidences. Doctors providing medicolegal services have to submit the exhibits/evidences collected during medical examination to forensic science laboratory for analysis and evaluation of the exhibits. Therefore, it is necessary for the doctors that they should have some idea regarding the set-up, functioning and services provided by these laboratories [3].

The Census of Publicly Funded Forensic Crime Laboratories (CPFFCL) is directed to federal, state, county, and municipal crime labs that are funded solely by the government or whose parent organization is a government agency. The CPFFCL includes agencies that employ one or more full-time scientists with a minimum of a bachelor's degree in chemistry, physics, biology, criminalistics, or a closely related forensic science field, and whose principal function is examining physical evidence in criminal matters and providing reports and testimony to courts of law regarding such evidence [4].

In the United States, crime labs (forensic lab) may be publicly or privately operated, although private laboratories typically do not respond to crime scenes to collect evidence. Public crime labs are organized at the city, county, state, or national level. A law enforcement agency that does not operate its own crime lab usually has free access to a higher level laboratory for analysis of their evidence. Most states have their own crime labs, for instance Oklahoma has the OSBI, and many other places have smaller yet still sufficient crime labs. The Los Angeles Police Department founded the first crime laboratory in the United States (1923), followed by the Bureau of Investigation (1926), forerunner to the Federal Bureau of Investigation. (Every Contact Leaves a Trace, Connie Fletcher, St. Martin's Press, New York, 2006, interview with crime lab director) [5].

According to a study by Pelicao [6], forensic toxicological lab analysis of both cases showed high concentration in the blood, stomach content and in the hepatic exudate (only Case 2), allowing the conclusion that these deaths occurred due to a cyanide acute intoxication. Case 1 has the manner of death well characterized as a suicide, mainly because of the findings at the crime scene, such as position of the body, indications of self-administration of the cyanide salt and the suicide note. For case 2, the manner of death has yet to be determined, pending investigation (accidental death and suicide are the main hypothesis).

In a study by Roya [7], Postmortem samples were analysed in forensic toxicology laboratory to confirm the presence of drugs in cadaver of suicidal cases. Drugs and poisons were analysed using thin layer chromatography, high performance liquid chromatography, gas chromatography/mass spectrometry, headspace gas chromatography and gas chromatography equipped with nitrogen phosphorus detector. Demographic data were collected from autopsy reports of all cases with confirmed self-poisoning suicidal cause of death. Results showed 
Citation: Vijay Kumar AG, Kumar U, Shivaramu MG, Vinay J (2018) Medico-Legal Autopsy \& Forensic Science Laboratory: Vital Tools of Criminal Justice System. J Forensic Med 3: 125. doi:10.4172/2472-1026.1000125

Page 3 of 3

that 674 cases of self-poisoning deaths were investigated during a fiveyear study period, of which $68.55 \%$ were male. The most often used suicide method was self-poisoning in young population. Phosphine gas liberated from aluminum phosphide tablets was the most toxic substance detected in postmortem samples (619 cases) followed by opioids, methamphetamine, organophosphates, cyanide and strychnine.

In a study by Sharma [8], forensic science laboratory detected Endosulfan, Pentazocine, Phenargan and Ketamine in the viscera and blood samples of all the deceased. Endosulfan was also detected in the urine sample of Mr. Chitarmal, food material (Rabdee) and in one syringe. Ketamine was detected in another syringe. The Postmortem examination, laboratory examination of viscera and blood of the deceased, food material and exhibits recovered from the suspect also confirmed the presence of Pentazocine, Phenargan, Ketamine and Endosulfan poison indicating homicidal poisoning.

\section{Conclusion}

With the rising population combined with inflation and economic downturns, there is an increased spurt of crime rates of all natures in the society. To ensure adequate and timely justice to the victims of offences a proper autopsy coupled with laboratory backing will go a long way in supplementing the work of police investigation in order to convert suspicion into a reasonable certainty of either guilt or innocence.

From the above study it can inferred that all crimes/crime scenes will leave foot prints in the form of physical evidence corpus delicti which needs to be handled by the doctor at autopsy level and further analyze, evaluated and opine taking the help of forensic science laboratory, so that criminal justice system is adequately served without any bias and prejudice, based only upon facts.

Doctors performing autopsy of complicated cases of unnatural deaths often rely upon Forensic Science Laboratory for their valuable opinion, so that offenders of various crime are brought to book or innocence protected from false charges.

This study shows that, in most of autopsies conducted, Forensic Science Laboratory service are taken and both played a significant role in aiding the criminal investigation process which ultimately strengthens the criminal justice system.

\section{References}

1. https://dfsl.maharashtra.gov.in/1035/Home

2. Anil A (2016) Forensic medicine and toxicology. Edition 1. Delhi: Avichal publishing company.Forensic science laboratory.

3. Rajesh B (2011) Principles of forensic medicine \& toxicology. Edition 1. Delhi: Jaypee brother's medical publishers. Forensic science laboratory.

4. https://www.bjs.gov/index.cfm?ty=dcdetail\&iid $=244$

5. https://en.wikipedia.org/wiki/Crime_lab

6. Pelicao FS, De-Paula DML, Botelho ED, Hampel G, Pissinate JF, et al. (2018) Forensic toxicological analysis in cyanide poisoning: Two case reports. J Toxicol Anal 1: 1-5.

7. Roya K, Maryam A, Maryam A, Masoud G, Kamran A. (2017) Forensic toxicology analysis of self-poisoning suicidal deaths in Tehran, Iran; trends between 2011-2015. DARU J Pharm Sci 25:15.

8. Sharma M, Khajja BS, Vashistha KN, Bairwa T, Sharma S, et al. (2010) Trace evidence crack a suicide proved homicide: A case study. J Forensic Res 1: 103. 